\title{
Involvement of Calcium in the Release of Immunoreactive $\beta$-Endorphin-Like Peptide from Dispersed Cells of the Neurointermediate Lobe of the Rat Pituitary Gland
}

\author{
Yoshio SAKODA, Masahide MUNEMURA, Yoshihiro FURUKI, \\ Yasuyuki HATADA, Masao MAEYAMA and Eishichi MIYAMOTO* \\ Department of Obstetrics and Gynecology and *Department of Pharmacology, \\ Kumamoto University Medical School, Kumamoto 860, Japan
}

Accepted December 3, 1984

\begin{abstract}
The presence of $\mathrm{Ca}^{2+}$ in the incubation medium was required for stimulation of the release of the immunoreactive $\beta$-endorphin-like peptide (IR- $\beta$-EP) from the dispersed cells of the neurointermediate lobe of rat pituitary gland by adenosine $3^{\prime}, 5^{\prime}$-monophosphate (cAMP) analogs, a phosphodiesterase inhibitor, $\mathrm{L}$-isoproterenol, cholera toxin and forskolin. The basal release observed in the absence of the stimulants was also dependent on the addition of $\mathrm{Ca}^{2+}$. A calcium antagonist (verapamil) inhibited the effects of the stimulants. A calcium ionophore (A23187) enhanced the release of IR- $\beta$-EP, but did not stimulate the formation of CAMP. These findings suggest that $\mathrm{Ca}^{2+}$ has the essential role in the release of $\beta$ endorphin from the neurointermediate lobe of rat pituitary gland.
\end{abstract}

$\beta$-Endorphin, an endogeneous opioid peptide, is known to be localized in the intermediate and anterior lobes of the rat pituitary gland (1). The intermediate lobe of the rat pituitary gland consists of a homogeneous population of cells synthesizing and secreting various peptides related to adrenocorticotropic hormone (ACTH) and lipotropin (LPH) derived from a common glycoprotein precursor, proopiomelanocortin (2-4). In fact, the spontaneous and Lisoproterenol-stimulated release of such peptides was shown during the in vitro superfusion of the rat anterior and neurointermediate lobes with Krebs-Ringer medium (5).

We have shown that the release of $\alpha$ MSH from the dispersed cells of the intermediate lobe of the rat pituitary gland is stimulated by CAMP and catecholamines (6). We have also reported that the release of the immunoreactive- $\beta$-endorphin-like peptide $(I R-\beta-E P)$ is regulated by CAMP analogs and several agents which stimulate the intracellular formation of CAMP (7). On the other hand. $\mathrm{Ca}^{2+}$ plays an important role in the stimulus-secretion coupling of neurotransmitters and hormones (8). The secretion of hormones from the anterior pituitary gland requires extracellular $\mathrm{Ca}^{2+}(9)$. Incubation of isolated anterior pituitary gland in $\mathrm{Ca}^{2+}$ free medium greatly diminishes the secretion of thyroid stimulating hormone (10). luteinizing hormone (11), ACTH (12, 13), prolactin (14) and growth hormone (15). Furthermore, it was reported that $\mathrm{Ca}^{2+}$ is involved in the release of $\alpha$-MSH from the intermediate lobe of the pituitary gland (16) and that $\mathrm{Ca}^{2+}$ has a coordinated action with CAMP for the release of $\alpha$-MSH from the tissue (17).

In the present study, we attempted to elucidate the role of $\mathrm{Ca}^{2+}$ and its interaction with CAMP for the release of $\beta$-endorphin from the dispersed cells of the neurointermediate lobe of rat pituitary gland.

\section{Materials and Methods}

Materials: The chemicals used were obtained from the following sources: Lisoproterenol, dibutyryl CAMP and cholera toxin, Sigma Chemical Co. (St. Louis, MO); 
A23187 and forskolin, Calbiochem (La Jolla, CA); 8-bromo CAMP, P-L Biochemicals, Inc. (Milwaukee, MA); and Earle's balanced salt solution (complete or without $\mathrm{Ca}^{2+}$ and $\mathrm{Mg}^{2+}$ ), Gibco (New York NY); verapamil, Eisai Co. Ltd. (Tokyo); ethylene glycol bis ( $\beta$-aminoethylether)- $N$, N,N', N'-tetraacetic acid (EGTA), Nakarai Chemicals Ltd. (Kyoto); and synthetic human $\beta$-endorphin, Protein Research Foundation (Minoo, Japan). Male rats of the Wistar strain, weighing between $250 \mathrm{~g}$ and $300 \mathrm{~g}$. were used in all experiments.

Preparation and incubation of dispersed cells from the neurointermediate lobe: The procedures used to obtain dispersed cells from the neurointermediate lobe as well as the standard incubation procedures were as described previously (6). Incubation was initiated by the addition of the dispersed cells to the sample tube.

A23187 was dissolved in a mixture of equal volumes of dimethylsulfoxide and ethanol to obtain a final concentration of $10 \mathrm{mM}$ and subsequently diluted in saline (containing $50 \mu \mathrm{g} / \mathrm{ml}$ ascorbic acid). Control samples contained vehicles. $\mathrm{Ca}^{2+}$-free Earle's balanced salt solution (EBSS) was prepared by adding $\mathrm{MgSO}_{4}$ to $\mathrm{Ca}^{2+}$ and $\mathrm{Mg}^{2+}$-free EBSS.

Determination of CAMP from dispersed cells: CAMP was determined by radioimmunoassay following succinylation according to the procedure of Honma et al. (18). utilizing kits supplied by Yamasa Co., Ltd., Japan.

Radioimmunoassay of $\beta$-endorphin: The determination of $\beta$-endorphin was performed by the methods of Matsumura et al. $(19,20)$. using synthetic human $\beta$-endorphin as a standard. Radioiodination of the $\beta$ endorphin was performed with 125 by the method of Hunter and Greenwood (21). The labeled peptide was subjected to gel filtration column chromatography on Sephadex G-25 (medium, $0.9 \times 18 \mathrm{~cm}$ column), and it was eluted with $0.02 \mathrm{M}$ phosphate buffer, $\mathrm{pH} 7.4$, containing $0.15 \mathrm{M}$ $\mathrm{NaCl}, 25 \mathrm{mM}$ EDTA, $0.1 \% \mathrm{NaN}_{3}$ and 500 $\mathrm{KIU} / \mathrm{ml}$ Trasylol. Anti- $\beta$-endorphin serum was a generous gift from Dr. M. Matsumura, the Department of Internal Medicine, Tokushima
University Medical School, Tokushima, Japan (22). The antibody showed only $4.5 \%$ cross-reactivity with human $\beta$-LPH on a mass basis, and it did not react with other peptides, including Leu-enkephalin, Metenkephalin, endorphins $(\alpha, \gamma$ and $\delta), \gamma$-LPH. 1-39ACTH, TRH, LH-RH and somatostatin.

The final volumes of the standards $(2-512$ $\mathrm{pg} /$ tube) and samples were adjusted to 0.3 $\mathrm{ml}$ by the addition of the assay medium (0.02M phosphate buffer, $\mathrm{pH} 7.4$, containing $0.15 \mathrm{M} \mathrm{NaCl}, 25 \mathrm{mM}$ EDTA, $0.1 \% \mathrm{NaN}_{3}$ and $500 \mathrm{KIU} / \mathrm{ml}$ Trasylol). Anti- $\beta$-endorphin serum $(100 \mu l)$ which was diluted to $1: 5,000$ with the assay buffer was added, and the incubation was carried out for $24 \mathrm{hr}$ at $4^{\circ} \mathrm{C}$.

${ }^{125} \mathrm{I}-\beta$-Endorphin $(10,000 \mathrm{cpm} / 100 \mu l)$ was then added, and the mixture was incubated for $24 \mathrm{hr}$ at $4^{\circ} \mathrm{C}$. The antibodybound antigen was precipitated by the addition of anti-rabbit $\gamma$-globulin goat serum (diluted to $1: 10$ ) and normal rabbit serum (diluted $1: 100$ ), followed by incubation at $4^{\circ} \mathrm{C}$ for $24 \mathrm{hr}$. Then the supernatant was decanted, and the radioactivity of the precipitate was counted. The average rate of binding was $42 \%$ in the sample without $\beta$ endorphin. A dose-related response in the radioimmunoassay was observed in the range of 4 to $256 \mathrm{pg}$ of $\beta$-endorphin/tube.

Statistics: The data were expressed as the mean \pm S.E. $\quad(n=3$ to 6$)$. Student's $t$-test (two-tailed) was employed to determine statistically significant difference between experimental groups of data. The procedures for calculation of the S.E. between two groups were as described previously (6).

\section{Results}

Effect of $\mathrm{Ca}^{2+}$ on the release of IR- $\beta$-EP stimulated by CAMP: A close relationship between the increase of CAMP formation and the stimulative effect of IR- $\beta$-EP release was previously reported (7). In the previous study. $\mathrm{Ca}^{2+}$ was originally included in the incubation medium, therefore the effect of $\mathrm{Ca}^{2+}$ on the release of IR- $\beta-E P$ was examined in the present study. $\mathrm{Ca}^{2+}$ was absolutely required for the stimulative effects of 8-bromo CAMP $(10 \mathrm{mM})$, dibutyryl CAMP $(10 \mathrm{mM})$ and 3-isobutyl-1-methyl xanthine (IBMX, $1 \mathrm{mM})$, although these 
agents had substantial effects in the presence of $1.8 \mathrm{mM} \mathrm{Ca}^{2+}$ (Fig. 1). The removal of $\mathrm{Ca}^{2+}$ from the incubation medium resulted in the abolishment of the effect of the agents. The basal release of IR- $\beta$-EP observed without the addition of CAMP analogs or phosphodiesterase inhibitor was also influenced by the addition of $\mathrm{Ca}^{2+}$.

The requirement for $\mathrm{Ca}^{2+}$ was observed for the effects of the agents which stimulate
cAMP formation (Table 1). L-Isoproterenol, cholera toxin and forskolin stimulated the release of IR- $\beta$-EP in the presence of $\mathrm{Ca}^{2+}$. However, the effects of these agents decreased in the absence of $\mathrm{Ca}^{2+}$. To further test the effect of $\mathrm{Ca}^{2+}, 1 \mathrm{mM}$ EGTA was added to the incubation medium with or without cholera toxin. The values of IR- $\beta$ EP released were $5.08 \pm 0.37$ and $3.10 \pm 0.12$ $\mathrm{ng} / 3 \times 10^{4}$ cells $/ 3 \mathrm{hr}$ in the absence and

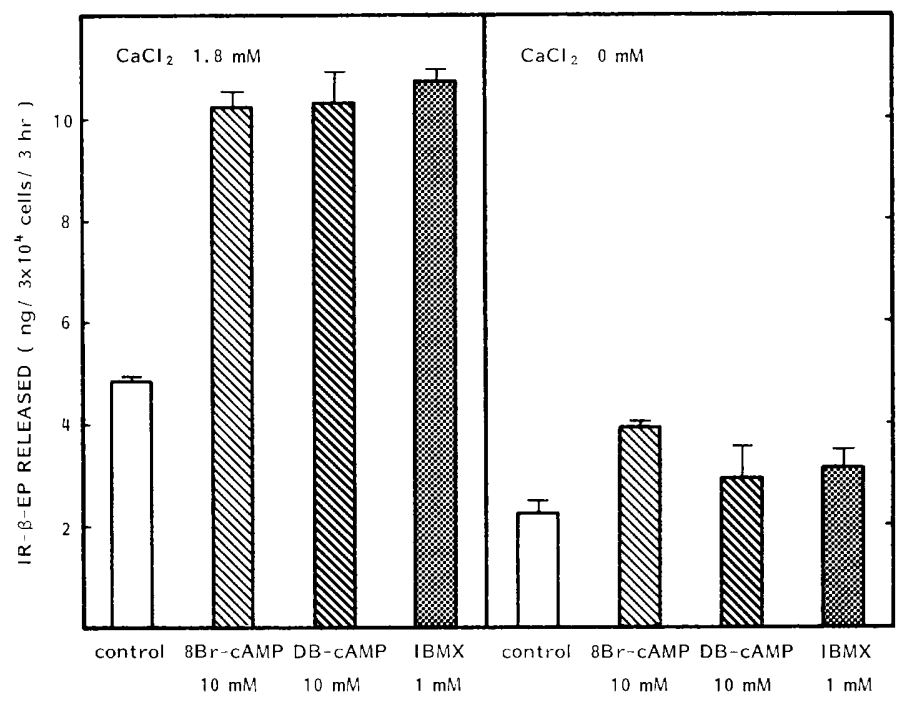

Fig. 1. Effect of $\mathrm{Ca}^{2+}$ on the release of IR- $\beta$-EP stimulated by CAMP analogs and phosphodiesterase inhibitor. Incubation was carried out for $3 \mathrm{hr}$ with the indicated drugs in the absence or presence of 1.8 $\mathrm{mM} \mathrm{CaCl}_{2}$ in EBSS-BSA, which had been equilibrated with a mixture of $95 \% \mathrm{O}_{2} / 5 \% \mathrm{CO}_{2}$ under standard conditions. The zero-time samples contained $2.47 \pm 0.13$ and $2.00 \pm 0.12 \mathrm{ng}$ of IR- $\beta$-EP in the absence or presence of $1.8 \mathrm{mM} \mathrm{CaCl}_{2}$, respectively. The values represent the extracellular amount of IR- $\beta$-EP released during $3 \mathrm{hr}$ incubation, are corrected for those of the zero-time samples and are expressed as the mean \pm S.E. $(n=3$ to 6$)$.

Table 1. Effect of $\mathrm{Ca}^{2+}$ on the release of IR- $\beta$-EP stimulated by L-isoproterenol, cholera toxin and forskolin

\begin{tabular}{|c|c|c|}
\hline \multirow[t]{2}{*}{ Addition } & \multicolumn{2}{|c|}{$\begin{array}{c}\text { IR- } \beta \text {-EP released } \\
\left(\mathrm{ng} / 3 \times 10^{4} \text { cells } / 3 \mathrm{hr}\right)\end{array}$} \\
\hline & No calcium & $1.8 \mathrm{mM} \mathrm{CaCl}_{2}$ \\
\hline None & $3.85 \pm 1.12$ & $5.97 \pm 0.07^{*}$ \\
\hline L-Isoproterenol (100 nM) & $4.51 \pm 0.24$ & $8.44 \pm 0.10^{*}$ \\
\hline Cholera toxin $(30 \mathrm{nM})$ & $4.97 \pm 0.57$ & $9.31 \pm 0.24^{\# k}$ \\
\hline Forskolin $(10 \mu \mathrm{M})$ & $4.44 \pm 0.20$ & $9.51 \pm 0.35^{*}$ \\
\hline
\end{tabular}

${ }^{*} \mathrm{P}<0.001$ vs. no calcium, ${ }^{*} \mathrm{P}<0.005$ vs. no calcium. Dispersed cells were incubated for 3 hr with the indicated drugs in the absence or presence of $1.8 \mathrm{mM} \mathrm{CaCl}_{2}$ under standard conditions. The values are expressed as the mean \pm S.E. ( $n=3$ to 6$)$. 
presence of EGTA, respectively, and $5.21 \pm 0.32$ and $9.41 \pm 0.23 \mathrm{ng} / 3 \times 10^{4}$ cells/ $3 \mathrm{hr}$ in the absence and presence of cholera toxin, respectively. These findings again show that the release of $\mid R-\beta-E P$ requires the presence of extracellular $\mathrm{Ca}^{2+}$.

The addition of $1 \mathrm{mM}$ EGTA to the $\mathrm{Ca}^{2+}$. free incubation medium was considered to completely remove the extracellular $\mathrm{Ca}^{2+}$. although a minute amount of contaminating $\mathrm{Ca}^{2+}$ may be present in only the $\mathrm{Ca}^{2+}$-free incubation medium without EGTA. The amounts of $I R-\beta$-EP released were $2.75 \pm 0.07$ and $2.71 \pm 0.27 \mathrm{ng} / 3 \times 10^{4}$ cells $/ 3 \mathrm{hr}$ in the $\mathrm{Ca}^{2+}$-free incubation medium in the absence and presence of EGTA, respectively. This indicates that the abolishment of the extracellular $\mathrm{Ca}^{2+}$ does not bring about the complete inhibition of the IR- $\beta$-EP release.

Effect of $\mathrm{Ca}^{2+}$ concentration on the release of IR- $\beta$-EP: The effect of $\mathrm{Ca}^{2+}$ concentration on the release of IR- $\beta$-EP was examined (Fig. 2). The release of IR- $\beta$-EP in the

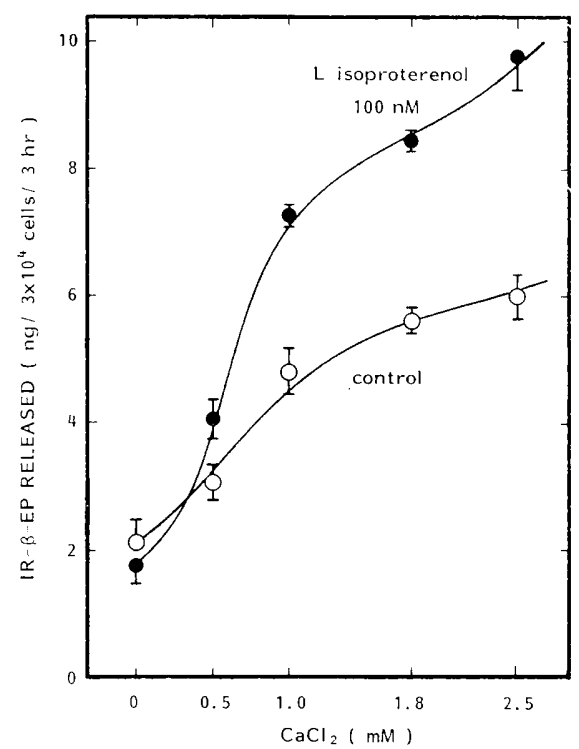

Fig. 2. Effect of $\mathrm{Ca}^{2+}$ concentration on the release of IR- $\beta$-EP in the absence and presence of $L$ isoproterenol. Incubation was carried out for $3 \mathrm{hr}$ with the indicated concentrations of $\mathrm{CaCl}_{2}$ in the absence ( ) or presence (O) of $100 \mathrm{nM} \mathrm{L-}$ isoproterenol in EBSS-BSA under standard conditions. The values are expressed as the mean \pm S.E. $(n=3$ to 6$)$. presence and absence of L-isoproterenol both increased by the addition of $\mathrm{Ca}^{2+}$ in a dose-dependent manner. It was still increasing at $2.5 \mathrm{mM} \mathrm{Ca}^{2+}$ which was the highest concentration tested.

Effect of verapamil on the release of IRB-EP: It was examined whether or not verapamil, a calcium antagonist, counteracts the effect of $\mathrm{Ca}^{2+}$ on the release of $I R-\beta$-EP. Verapamil significantly had an inhibitory effect at $10^{-7} \mathrm{M}$ and decreased the release of IR- $\beta$-EP with the increase of the concentration in the presence of $\mathrm{L}$-isoproterenol (Fig. 3). Meantime, verapamil had no effect on the release in the absence of $L$-isoproterenol. These inhibitory effects of verapamil on the release of IR- $\beta$-EP were also observed for the stimulative effects of 8-bromo cAMP. dibutyryl CAMP and IBMX (Table 2A) and cholera toxin and forskolin (Table 2B).

Effect of A23187 on the release of IR- $\beta$ EP: The effect of A23187. a calcium

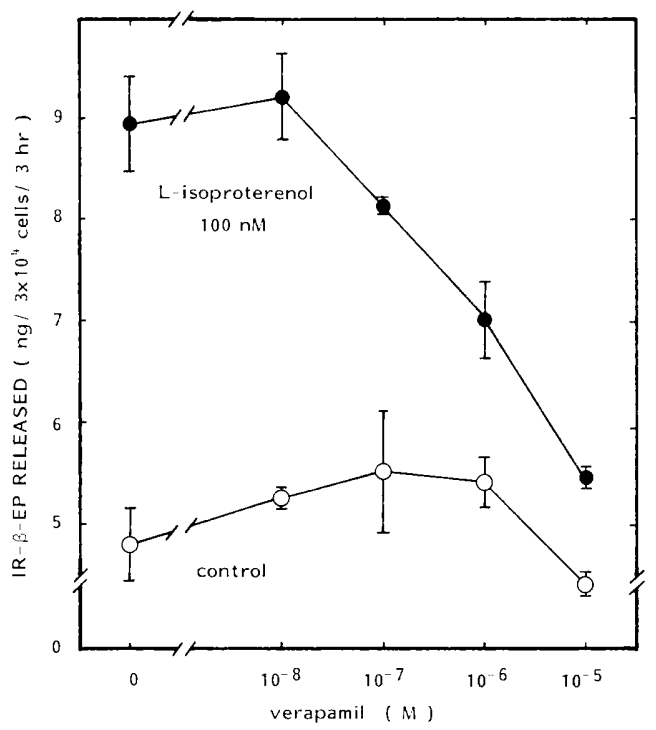

Fig. 3. Effect of verapamil on the release of IR- $\beta$ $E P$ in the absence and presence of $\mathrm{L}$-isoproterenol. Dispersed cells were incubated for $3 \mathrm{hr}$ with the indicated concentrations of verapamil in the absence $(\bigcirc)$ or presence $(\mathbf{O})$ of $100 \mathrm{nM} \mathrm{L}$ isoproterenot in EBSS-BSA containing $1.8 \mathrm{mM}$ $\mathrm{CaCl}_{2}$ under standard conditions. The zero-time sample contained $2.33 \pm 0.19 \mathrm{ng}$ of IR- $\beta$-EP. The values are corrected for that of the zero-time sample and expressed as the mean \pm S.E. $(n=3$ to 6$)$. 
Table 2. Effect of verapamil on the release of IR- $\beta$-EP stimulated by CAMP analogs, phosphodiesterase inhibitor, cholera toxin and forskolin

Addition

(A) None

8-Bromo CAMP $(10 \mathrm{mM})$

Dibutyryl cAMP (10 mM)

3-|sobutyl-1-methy| xanthine (1 mM)

(B) None

Cholera toxin (30 nM)

Forskolin $(10 \mu \mathrm{M})$

IR- $\beta$-EP released

( $\mathrm{ng} / 3 \times 10^{4}$ cells $/ 3 \mathrm{hr}$ )

No verapamil

$5.77 \pm 0.31$

$10.27 \pm 0.56$

$10.50 \pm 0.52$

$9.30 \pm 0.13$

$5.90 \pm 0.07$

$10.30 \pm 0.47$

$10.03 \pm 0.53$
$10 \mu \mathrm{M}$ verapamil

$5.17 \pm 0.31$

$6.60 \pm 0.67$

$6.57 \pm 0.10^{*}$

$6.83 \pm 0.41^{*}$

$5.77 \pm 0.18^{\text {\#k }}$

$6.23 \pm 0.35^{*}$

$5.23 \pm 0.42 *$

${ }^{\#} \mathrm{P}$, not significant. ${ }^{*} \mathrm{P}<0.005$ vs. no verapamil. Dispersed cells were incubated for $3 \mathrm{hr}$ with the indicated drugs in the absence or presence of $10 \mu \mathrm{M}$ verapamil in EBSS-BSA containing $1.8 \mathrm{mM} \mathrm{CaCl}_{2}$ under standard conditions. The values are expressed as the mean \pm S.E. $(n=3$ to 6$)$.

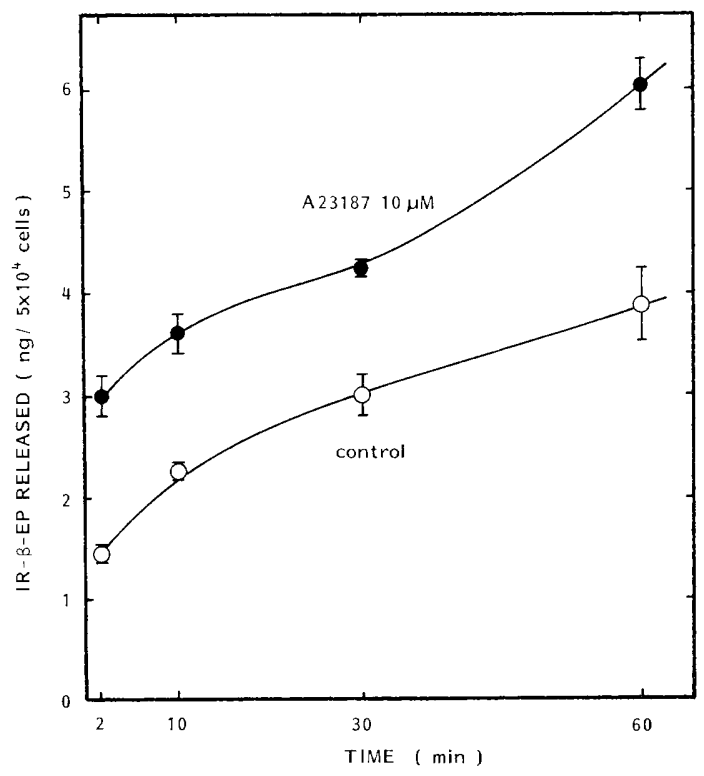

Fig. 4. Effect of $A 23187$ on the release of IR- $\beta$-EP during the time course. Dispersed cells were incubated for the indicated times in the absence (O) or presence (O) of $10 \mu \mathrm{M} \mathrm{A23187} \mathrm{in} \mathrm{EBSS-}$ BSA containing $1.8 \mathrm{mM} \mathrm{CaCl}_{2}$ under standard conditions. The zero-time sample contained 4.40 $\pm 0.12 \mathrm{ng}$ of IR- $\beta$-EP. The values are corrected for that of the zero-time sample and expressed as the mean \pm S.E. $(n=3$ to 6$)$.

ionophore, on the release of IR- $\beta$-EP was examined (Fig. 4). A23187 increased the release of IR- $\beta$-EP higher than the control (without A23187) during the time course.

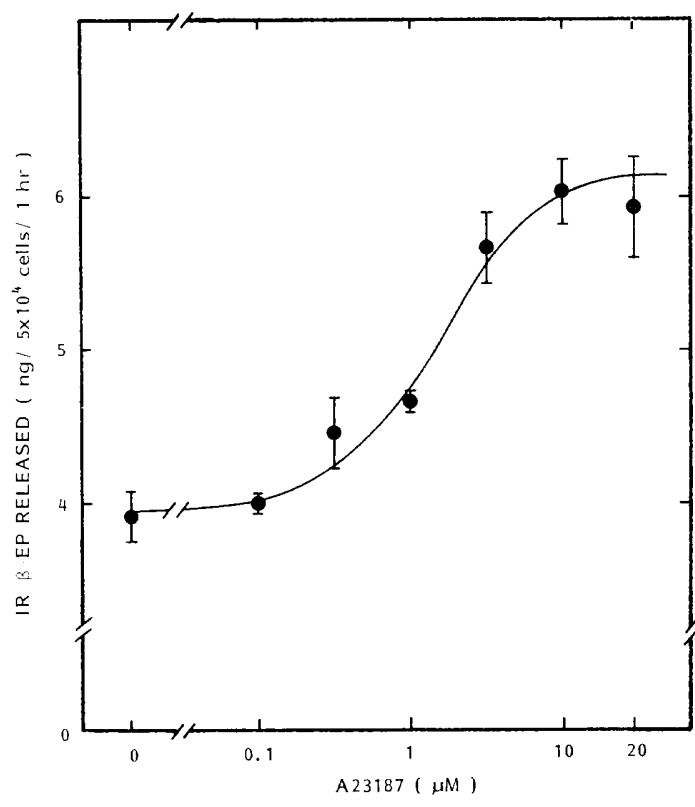

Fig. 5. Effect of A23187 concentration on the release of $\mid R-\beta-E P$. Dispersed cells were incubated for $1 \mathrm{hr}$ with the indicated concentrations of $\mathrm{A} 23187$ in EBSS-BSA containing $1.8 \mathrm{mM} \mathrm{CaCl}_{2}$ under standard conditions. The values are expressed as the mean $\pm S E$. $(n=3$ to 6$)$.

although the control value increased in the course of time. The dose-response relationship between the concentration of A23187 and the release of $I R-\beta-E P$ is shown in Fig. 5 . The concentration of $A 23187$ required to give the half-maximal release was $1.0 \mu \mathrm{M}$. 

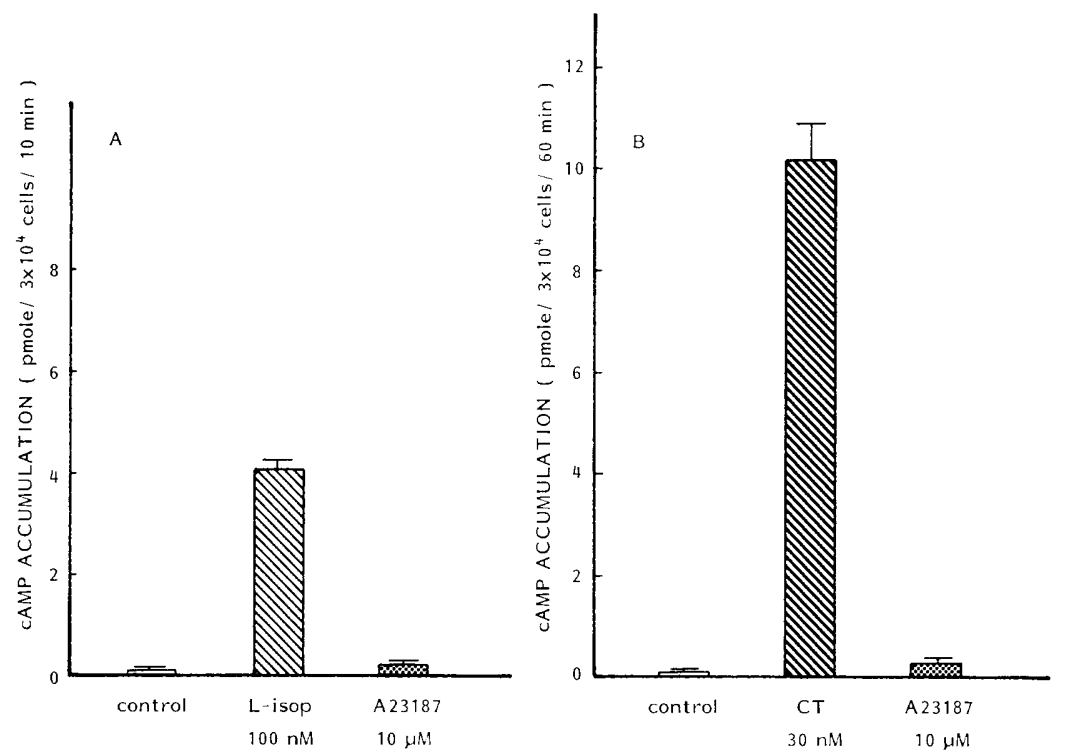

Fig. 6. Effect of A23187 on CAMP accumulation. A) Dispersed cells were incubated for $10 \mathrm{~min}$ in the absence (control) and presence of $100 \mathrm{nM} \mathrm{L}$-isoproterenol or $10 \mu \mathrm{M} \mathrm{A} 21387$ under standard conditions. B) Dispersed cells were incubated for $60 \mathrm{~min}$ in the absence (control) and presence of $30 \mathrm{nM}$ cholera toxin or $10 \mu \mathrm{M} \mathrm{A} 23187$ under standard conditions. Incubation was carried out in EBSS-BSA containing $10 \mathrm{mM}$ theophylline and $1.8 \mathrm{mM} \mathrm{CaCl}_{2}$ under standard conditions. The amount of cAMP measured represents the sum of CAMP in the cells and incubation medium. The zero-time sample contained $200 \pm 29$ fmole per $3 \times 10^{4}$ cells. The values are corrected for that of the zero-time sample and expressed as the mean \pm S.E. $(n=3$ to 6$)$.

The maximal release was attained at $10 \varkappa \mathrm{M}$ of A23187.

Effect of A23187 on cAMP accumulation: As shown in the previous study (7), Lisoproterenol and cholera toxin stimulated the formation of CAMP in the dispersed cells of the intermediate lobe of the rat pituitary gland (Fig. 6). The addition of $10 \mu \mathrm{M}$ A23187 which stimulates the release of IR$\beta$-EP (Fig. 5) had no effect on the formation of cAMP in the dispersed cells incubated for $10 \mathrm{~min}$ (Fig. 6A) and $60 \mathrm{~min}$ (Fig. 6B). Under the conditions, L-isoproterenol (Fig. 6A) and cholera toxin (Fig. 6B) each stimulated the accumulation of CAMP.

\section{Discussion}

A series of biologically active peptides related to ACTH and lipotropin ( $\mathrm{LPH}$ ) is formed in the corticotrophs of the anterior lobe and the melanotrophs of the intermediate lobe of the pituitary gland by proteolytic cleavage of a common precursor molecule (2-4). $\beta$-Endorphin, an endogeneous opioid, has the same amino acid sequence as residues $61-91$ of $\beta$-LPH. Immunocytofluorescence techniques with well-characterized antisera to $\beta$-endorphin indicate the presence of this peptide in all cell elements of the pars intermedia of the rat hypophysis and discrete cells of the pars distalis free from the neurohypophysis (1). It is considered that the results obtained from the preparation of dispersed cells derived from the neurointermediate lobe accurately reflect the function of this tissue $(6,7)$.

$\beta$-Adrenoceptor which enhances the release of $\alpha-\mathrm{MSH}$ is known to occur in the parenchymal cells of the intermediate lobe (23). Previous studies have characterized the $\beta$-adrenergic receptors which are present on the intermediate lobe cells of rat pituitary gland. Based on biochemical criteria, these $\beta$-adrenergic receptors belong to the $\beta_{2}$ subcategory. Evidence has been presented to support the view that $\beta$-adrenergic stimu- 
lation of $\alpha$-MSH release involves an increase in adenylate cyclase activity $(6,24)$.

The effect of cholera toxin on the release of $\alpha$-MSH from the dispersed cells of the intermediate lobe was also investigated. Thus it proved that cholera toxin enhances the accumulation of CAMP and stimulates the release of $\alpha$-MSH (17).

Furthermore, forskolin has been reported to stimulate adenylate cyclase activity, CAMP production and $\alpha$-MSH release from the intermediate lobe of the rat pituitary gland (25). The effect of forskolin is probably mediated through interaction with the catalytic subunit of the associated protein of adenylate cyclase (26). Similarly, stimulation of $\beta$-adrenergic receptor or administration of CAMP analogs and consequent accumulation of CAMP in the dispersed cells of the intermediate lobe resulted in the release of IR- $\beta$-EP (7). Our present findings demonstrate that although CAMP stimulates the release of IR- $\beta$-EP from the dispersed cells of the neurointermediate lobe, $\mathrm{Ca}^{2+}$ is essentially required. Similar results on the effects of $\mathrm{Ca}^{2+}$ and cAMP were reported for the release of $\alpha$-MSH from the dispersed cells of the neurointermediate lobe (17).

Verapamil, a calcium antagonist, has an inhibitory effect on the voltage-dependent calcium channel (27). Verapamil actually inhibited the release of $\mathrm{GH}$, prolactin. TSH and $\mathrm{LH}$ from the anterior pituitary gland ( 9 , $10,15,28,29)$. In the present study, verapamil also inhibited the effects of $L$ isoproterenol, CAMP analogs, the phosphodiesterase inhibitor, cholera toxin and folskolin on the release of IR- $\beta$-EP. The removal of the extracellular $\mathrm{Ca}^{2+}$ and the higher concentration of verapamil did not completely inhibit the release of IR- $\beta$-EP from the dispersed cells. The basal level of the IR- $\beta$ EP release were observed in both cases. The results were consistent with those reported previously $(10,14,17)$. At present, there is no proper explanation for these findings.

However, it may be likely that the $\mathrm{Ca}^{2+}$ release from the intracellular $\mathrm{Ca}^{2+}$ storage sites continues at a low concentration even in the absence of the extracellular $\mathrm{Ca}^{2+}$ and that this may maintain the basal level of the IR- $\beta$-EP release.
A23187, a calcium ionophore, stimulated the release of IR- $\beta$-EP from the dispersed cells of the neurointermediate lobe in a dosedependent manner ranging from $0.1 \mu \mathrm{M}$ to $20 \mu \mathrm{M}$. The accumulation of CAMP was not stimulated by $A 23187$. It has been reported that A23187 stimulates hormone secretion in the anterior pituitary gland and many other cells (30) and increases the uptake of ${ }^{45} \mathrm{Ca}$ and the release of $\alpha$-MSH from the neurointermediate lobe of rat pituitary gland (17). In contrast to our results, Shettini et al. (31) reported that $A 23187$ increased the formation of CAMP and the release of prolactin in the anterior pituitary cells. The difference between the results is unclear at present.

These results suggest that the effects of verapamil and A23187 may be exerted by the inhibition and enhancement, respectively, of $\mathrm{Ca}^{2+}$ influx through the membrane. In view of the fact that A23187 stimulates the release of IR- $\beta$-EP without enhancing the accumulation of CAMP in the present study, $\mathrm{Ca}^{2+}$ may have an essential role in the release of the hormone in the neurointermediate lobe. On the other hand, CAMP may modulate the degree of the release of the hormone in the presence of $\mathrm{Ca}^{2+}$. The possibility is not ruled out that CAMP may affect the mobilization of $\mathrm{Ca}^{2+}$ into the cells.

Acknowledgments: The authors wish to thank Dr. M. Matsumura, the Department of Internal Medicine, Tokushima University Medical School, for his generous gift of $\beta$-endorphin antiserum. This work was supported in part by Grants-in-aid for Scientific Research (No. 58570693) from the Ministry of Education, Science and Culture of Japan.

\section{References}

1 Bloom, F., Battenberg, E., Rossier, J., Ling, N., Leppaluoto, J., Vargo, T.M. and Guillemin, R.: Endorphins are located in the intermediate and anterior lobes of the pituitary gland, not in the neurohypophysis. Life Sci. 20, 43-48 (1977)

2 Rubinstein, M., Stein, S. and Udenfriend, S.: Characterization of pro-opiocortin, a precursor to opioid peptides and corticotropin. Proc. Natl. Acad. Sci. U.S.A. 75, 669-671 (1978)

3 Mains, R.E. and Eipper, B.A.: Synthesis and secretion of corticotropins, melanotropins and endorphins by rat intermediate pituitary cells. J. Biol. Chem. 254, 7885-7894 (1979)

4 Nakanishi, S., Inoue, A., Kita, T., Nakayama, M., 
Chang, A.C.Y., Cohen, S.N. and Numa, S.: Nucleotide sequence of cloned cDNA for bovine corticotropin- $\beta$-lipotropin precursor. Nature 278 , 423-427 (1979)

5 Vermes, I., Mulder, G.H., Smelik, P.G. and Tilders, F.J.H.: Differential control of $\beta$ endorphin/ $\beta$-lipotropin secretion from anterior and intermediate lobes of the rat pituitary gland in vitro. Life Sci. 27, 1761-1768 (1980)

6 Munemura, M., Eskay, R.L. and Kebabian, J.W.: Release of $\alpha$-melanocyte-stimulating hormone from dispersed cells of the intermediate lobe of the rat pituitary gland: Involvement of catecholamines and adenosine 3',5'-monophosphate. Endocrinology 106, 1795-1803 (1980)

7 Furuki, Y.: Release mechanism of $\beta$-endorphinlike immunoreactivity from dispersed cells of the neurointermediate lobe of rat pituitary gland. Acta Obstet. Gynaecol. Japon. 35, 1604-1610 (1983)

8 Douglas, W.W.: Stimulus-secretion coupling; The concept and clues from chromaffin and other cells. Br. J. Pharmacol. 34, 451-474 (1968)

9 Conn, P.M., Marian, J., McMillian, M., Stern, J., Rogers, D., Hamby, M., Penna, A. and Grant, E.: Gonadotropin-releasing hormone action in the pituitary: A three step mechanism. Endocr. Rev. 2, 174-185 (1981)

10 Geras, E., Rebecchi, M.J. and Gershengorn, M.C.: Evidence that stimulation of thyrotropin and prolactin secretion by thyrotropin-releasing hormone occur via different calcium-mediated mechanism; Studies with verapamil. Endocrinology 110, 901-906 (1982)

11 de Koning, J., Tijssen, A.M.I., van Dieten, J.A.M.J. and van Rees, G.P: Effect of $\mathrm{Ca}^{2+}$ deprivation on release of luteinizing hormone induced by luteinizing hormone releasing hormone from female rat pituitary glands in vitro. J. Endocrinol. 94, 11-20 (1982)

12 Briaud, B., Koch, B., Lutz-Bucher, B. and Mialhe, $C .:$ In vitro regulation of $\mathrm{ACTH}$ release from neurointermediate lobe of rat hypophysis. Neuroendocrinology 30, 262-267 (1980)

13 Richardson, U.I.: Adrenocorticotropin secretion by mouse pituitary tumor cells in culture; The role of $\mathrm{Ca}^{2+}$ in stimulated and somatostatininhibited secretion. Endocrinology 113, 62-68 (1983)

14 Scammel, J.G. and Dannies, P.S.: Veratridine and ouabain stimulate calcium-dependent prolactin release. Endocrinology 113, $1228-$ 1235 (1983)

15 Kraicer, J. and Spence, J.W.: Release of growth hormone from purified somatotrophs; Use of high $\mathrm{K}^{+}$and ionophore $\mathrm{A} 23187$ to elucidate interrelations among $\mathrm{Ca}^{++}$, adenosine $3^{\prime}, 5^{\prime}$ monophosphate, and somatostatin. Endocrinology 108, 651-657 (1981)

16 Tomiko, S.A., Taraskevich, P.S. and Douglas, W.W.: Potassium-induced secretion of melanocyte-stimulating hormone from isolated pars intermedia cells signals participation of voltage-dependent calcium channels in stimulussecretion coupling. Neuroscience 6, 2259-2267 (1981)

17 Tsuruta, K., Grewe, C.W., Cote, T.E., Eskay, R.L. and Kebabian, J.W.: Coordinated action of calcium ion and adenosine $3^{\prime}, 5^{\prime}$-monophosphate upon the release of $\alpha$-melanocyte-stimulating hormone from the intermediate lobe of the rat pituitary gland. Endocrinology 110, 1133-1140 (1982)

18 Honma, M., Satoh, T., Takezawa, J. and Ui, M.: An ultrasensitive method for the simultaneous determination of cyclic AMP and cyclic GMP in small-volume samples from blood and tissue. Biochem. Med. 18, 257-273 (1977)

19 Matsumura, M., Yamanoi, A., Yamamoto, S. and Saito, S.: In vivo and in vitro effects of substance $P$ on the release of $\beta$-endorphin-like immunoreactivity. Neuroendocrinology 35, 163168 (1982)

20 Matsumura, M., Yamanoi, A., Yamamoto, S. and Saito, S.: In vivo and in vitro effects of cholecystokinin octapeptide on the release of $\beta$-endorphin-like immunoreactivity. Neuroendocrinology 36, 443-448 (1983)

21 Hunter, W.M. and Greenwood, F.C.: Preparation of iodine-131 labelled human growth hormone on high specific activity. Nature 194, 495-496 (1962)

22 Guillemin, R., Ling, N. and Vargo, T.: Radioimmunoassays for $\alpha$-endorphin and $\beta$-endorphin. Biochem. Biophys. Res. Commun. 77, 361-366 (1977)

23 Bower, A., Hadley, M.E. and Hruby, V.J.: Biogenic amines and control of melanophore stimulating hormone release. Science 184,70 72 (1974)

24 Cote, T.E., Eskay, R.L., Frey, E.A., Grewe, C.W., Munemura, M., Stoof, J.C., Tsuruta, K. and Kebabian, J.W.: Biochemical and physiological studies of the beta-adrenoceptor and the D-2 dopamine receptor in the intermediate lobe of the rat pituitary gland: A review. Neuroendocrinology 35, 217-224 (1982)

25 Miyazaki, K., Goldman, M.E. and Kebabian, J.W.: Forskolin stimulates adenylate cyclase activity, adenosine $3^{\prime}, 5^{\prime}$-monophosphate pro- 
duction and peptide release from the intermediate lobe of the rat pituitary gland. Endocrinology 114, 761-766 (1984)

26 Seamon, K.B. and Daly, J.W.: Forskolin; A unique diterpene activator of cyclic AMP-generating system. J. Cyclic Nucleotide Res. 7, 201-224 (1981)

27 Zoster, T.T.: Calcium antagonists. Am. Heart J. 99, 805-810 (1980)

28 Ozawa, S. and Kimura, N.: Calcium channel and prolactin release in rat clonal pituitary cells: Effects of verapamil. Am. J. Physiol. 243, E68-E73 (1982)

29 Stachura, M.E.: Verapamil; Influence upon basal and stimulated rat growth hormone and prolactin release in vitro. Proc. Soc. Exp. Biol. Med. 173, 109-117 (1983)

30 Tam, S.W. and Dannies, P.S.: Dopaminergic inhibition of ionophore A23187-stimulated release of prolactin from rat anterior pituitary cells. J. Biol. Chem. 255, 6595-6599 (1980)

31 Schettini, G., Cronin, M.J. and MacLeod, R.M.: Adenosine $3^{\prime}, 5^{\prime}$-monophosphate (CAMP) and calcium-calmodulin interaction in the control of prolactin secretion: Evidence for dopamine inhibition of CAMP accumulation and prolactin release after calcium mobilization. Endocrinology 112, 1801-1807 (1983) 